\title{
The Effect of Moringa Oleifera on the Life Outcome of Pregnant and Breastfreeding Mothers: Literature Review
}

\author{
1,2 Nur Ulmy Mahmud, Tahir Abdullah ${ }^{3}$, Arsunan, A.A ${ }^{3}$, Burhanuddin Bahar ${ }^{3}$, Veni Hadju, Muhammad \\ Syafar $^{3}$ \\ ${ }^{1}$ Postgraduate School Students, Faculty of Public Health, Universitas Hasanuddin, Indonesia, ${ }^{2}$ Lecturer of Faculty \\ of Public Health, Universitas Muslim Indonesia, ${ }^{3}$ Lecturer of Faculty of Public Health, Universitas Hasanuddin, \\ Indonesia
}

\begin{abstract}
Background: As an extraordinary plant, moringa oleifera is nutritios plant which is also a source of medicine having content different from other common plants. Moringa also contains all elements of essential amino acids. Moringa is believed to have potential to decrease malnutrition, hunger, increase breast milk volume as well as prevent and heal various diseases due to its nutritious content. Objective: This literature study aims to obtain input regarding the effect of moringa oleifera on the life outcome of the pregnant and breastfeeding mothers in Indonesia. Method: The literature review was conducted through Google scholar and electronic database of PubMed, Clinical Key and Springer. The keywords of Moringa oleifera, pregnancy, galactogogue, breastfeeding, nutrition, health and diseases were used to search original research or literature review on both open access English national and international journal. As many as 24 articles published in 2009 to 2019 were reviewed and synthesized using unsystematic narrative review, obtaining suitable 26 articles and unsuitable 14 articles. Results: This research found that moringa oleifera is good for pregnant and breast feeding mothers. Conclusion: As one of alternative plants, Moringa oleifera is believed to have potential in decreasing malnutrition, hunger, preventing BBLR, increasing breast milk volume and quality, increasing HB level and preventing anaemia which commonly happens among the pregnant mothers.
\end{abstract}

Keywords: Moringa oleifera, pregnant mothers, breastfeeding mothers

\section{Introduction}

Children's growth and development is significantly determined during the pregnancy period which is a critical phase. Nutrition is really important during the pregnancy period as it supports the fetus growth and development. Study proved that mothers with poor nutrition status causes disturbed fetus growth, gives birth to baby with low birth weight and causes malnutrition between generations ${ }^{1}$

Giving exclusive breastfeeding for 6 months is one form to improve nutrition in infant, Education lactation can improve knowledge, attitudes and behavior of mother to give breastfeeding up to 6 months, several determinant factors of exclusive breastfeeding in 0-6 months infants were giving colostrum, mother's work, family income, mother's education, and mother's knowledge about the benefits of exclusive breastfeeding. Iron deficiency in early life can cause brain development disorders and other developmental effects. Iron is very important for brain development, anemia causes metabolic energy deficiency and memory function ${ }^{2-4}$.

Nutrition has primary role in mothers' and children's health. Poor mothers' nutritional status is related to adverse birth effect. However, there is complex relationship between the mothers' nutrition and the effect of the birth since it is affected by many biological, socio-economical and demographical factors in different population. Nutrition intervention is a way to improve the birth and quality of life as well as decrease the mortality, pain and health from understanding the correlation between mothers' nutrition and effect of birth. The intervention can be developed through understanding the correlation between mothers' nutrition and the effect of birth ${ }^{1}$. 
Moringa leaves also contains all elements of essential amino acids. These various nutrition is an extraordinary source from plant. Meanwhile six tablespoons of Moringa leaves powder can met the daily needs of calcium and iron of pregnant and breastfeeding mothers, can reduce the incidence of morbidity in infants $0-5$ months in the district $^{5-8}$. This research aimed to perform literature review in order to obtain input regarding the effect of Moringa oleifera on the life outcome of pregnant and breastfeeding mothers in Indonesia.

\section{Materials and Method}

The design of this research was qualitative research through literature review. This research was conducted in Desember 2019 on various research results. This literature review was done through Google scholar, and electronic database of PubMed, Clinical Key and Springer with keywords of Moringa oleifera, pregnancy, galactogogue, breastfeeding, nutrition, health and diseases to find out the original research or the review of literature review on both open access English national and international journal. As many as 24 articles were reviewed and synthesized using unsystematic narrative review, obtaining suitable 26 articles and unsuitable 14 articles.

Table 1. Document eligibility criteria

\begin{tabular}{|l|l|l|}
\hline CRITERIA & ACTION & DESCRIPTOR \\
\hline Publication date & Inclusion & $2009-2019$ \\
\hline Region & Inclusion & Indonesia \\
\hline & & India \\
\hline & & Bangladesh \\
\hline Setting intervention & & Nigeria \\
\hline & Inclusion & Pregnant mothers \\
& & Breastfeeding mothers \\
\hline Language & Exclusion & Experimental animal \\
\hline & Inclusion & Bahasa Indonesia \\
\hline
\end{tabular}

\section{Results}

Literature review result can be seen on Table 2 
Table 2. Comparison of moringa oleifera for each literature

\begin{tabular}{|c|c|c|c|c|c|}
\hline No & Authors & $\begin{array}{l}\text { Intervention } \\
\text { Setting }\end{array}$ & Study Design & Tool type & Report outcome \\
\hline 1 & (9) & Pregnant mothers & $\begin{array}{l}\text { Randomized, } \\
\text { double-blind, } \\
\text { controlled trials }\end{array}$ & $\begin{array}{l}\text { Questionnaire, } \\
\text { intervention }\end{array}$ & $\begin{array}{l}\text { The provision of Moringa leaves extract to } \\
\text { pregnant mother who were also informal } \\
\text { workers can decrease the stress and improve the } \\
\text { nutritional status but cannot decrease the DNA } \\
\text { damage. }\end{array}$ \\
\hline 2 & (10) & $\begin{array}{l}\text { Breastfeeding } \\
\text { mothers }\end{array}$ & literature explained & Literature & $\begin{array}{l}\text { Moringa oleifera can prevent anemia on pregnant } \\
\text { mothers. Study on moringa extract proved that } \\
\text { government and community should utilize } \\
\text { this local food to prevent anemia and harmful } \\
\text { pregnancy }\end{array}$ \\
\hline 3 & (11) & Pregnant mothers & $\begin{array}{l}\text { Randomized } \\
\text { Double Blind, } \\
\text { Posttest controlled }\end{array}$ & $\begin{array}{l}\text { Questionnaire, } \\
\text { intervention }\end{array}$ & $\begin{array}{l}\text { Provision of Moringa leaves extract to prevent } \\
\text { anemia and DNA damage due to oxidative stress } \\
\text { on pregnant mothers, as well as prevent BBLR }\end{array}$ \\
\hline 4 & (12) & Pregnant mothers & $\begin{array}{l}\text { double blind, } \\
\text { randomized control } \\
\text { trial study, pretest- } \\
\text { posttest controlled }\end{array}$ & $\begin{array}{l}\text { Questionnaire, } \\
\text { intervention }\end{array}$ & $\begin{array}{l}\text { Moringa oleifera leaves extract significantly } \\
\text { increase the hemoglobin level on pregnant, } \\
\text { prevent ferritin serum to decrease up to } 50 \% \text {. } \\
\text { Further research needs to be conducted to ensure } \\
\text { the validity of Moringa leaves extract dose. }\end{array}$ \\
\hline 5 & (13) & $\begin{array}{l}\text { Pregnant and } \\
\text { breastfeeding } \\
\text { mothers }\end{array}$ & $\begin{array}{l}\text { Comprehensive } \\
\text { study }\end{array}$ & $\begin{array}{l}\text { Questionnaire, } \\
\text { intervention }\end{array}$ & $\begin{array}{l}\text { Moringa oleifera leaves powder can increase } \\
\text { mothers' Hb level, but cannot increase the } \\
\text { mothers' weight }\end{array}$ \\
\hline 6 & (5) & Pregnant mothers & $\begin{array}{l}\text { Quasi experimental } \\
\text { research of one } \\
\text { group pretest - } \\
\text { posttest design }\end{array}$ & $\begin{array}{l}\text { Questionnaire, } \\
\text { intervention }\end{array}$ & $\begin{array}{l}\text { Moringa leaves powder can increase pregnant } \\
\text { mothers' } \mathrm{Hb} \text { level who has anemia }\end{array}$ \\
\hline 7 & (14) & Pregnant mothers & $\begin{array}{l}\text { Randomized, } \\
\text { double-blind, } \\
\text { placebo-controlled } \\
\text { study }\end{array}$ & $\begin{array}{l}\text { Questionnaire, } \\
\text { intervention }\end{array}$ & $\begin{array}{l}\text { Moringa leaves extract can increase iron } \\
\text { deficiency anemia on women }\end{array}$ \\
\hline 8 & (15) & $\begin{array}{l}\text { Breastfeeding } \\
\text { mothers }\end{array}$ & $\begin{array}{l}\text { randomized } \\
\text { controlled double- } \\
\text { blind design }\end{array}$ & $\begin{array}{l}\text { Questionnaire, } \\
\text { intervention }\end{array}$ & $\begin{array}{l}\text { The provision of Moringa extract and flour } \\
\text { can improve breast milk volume in which the } \\
\text { improvement of breast milk was higher on group } \\
\text { who obtained Moringa leaves extract compared } \\
\text { to the group who obtain moringa leaves flour. } \\
\text { However, it did not affect the quality of breast } \\
\text { milk (iron, vitamin C and vitamin E) }\end{array}$ \\
\hline 9 & (16) & $\begin{array}{l}\text { Pregnant and } \\
\text { breastfeeding } \\
\text { mothers }\end{array}$ & $\begin{array}{l}\text { non-randomized } \\
\text { group pre-post } \\
\text { test }\end{array}$ & $\begin{array}{l}\text { Questionnaire, } \\
\text { intervention }\end{array}$ & $\begin{array}{l}\text { Provision of honey and Moringa leaves } \\
\text { extract on pregnant mothers who were } \\
\text { passive smoker can decrease oxidative } \\
\text { stress and DNA damage and prevent low } \\
\text { birth weight. }\end{array}$ \\
\hline
\end{tabular}

After reviewing the 14 articles, it was known that among the articles, several of them commonly explains that Moringa oleifera is able to increase $\mathrm{Hb}$ level on pregnant mothers while the other several articles explain the other benefits of Moringa oleifera for having potential to decrease malnutrition, hunger, prevent DNA damage due to stress on pregnant mothers, prevent the occurrence of anemia on pregnant mothers, prevent low birth weight and increase the breast milk volume. However, one of the articles explain the consuming Moringa oleifera cannot increase the weight of pregnant mothers and does not affect the breast milk quality. 


\section{Discussion}

1. Moringa oleifera

Moringa oleifera Lam (synonym: Moringa pterygosperma Gaertner) or commonly known as kelor is the most popular species of Moringacae genus species. Moringa oleifera grows in the form of three and has long live (perenial) with height of 7-12 meters. It has woody stems (lignosus), upright, and having thin skin, dirty white colour and rough surface. It also has simpodial branching directing uprightly or tilted and tend to grow in line and extendedly. It can grow both in lowland and highland up to height of $\pm 1000 \mathrm{~m}$ above the sea level, planted frequently as boundary or fence on house yard or field ${ }^{22}$.

Fuglie LJ 1999 conducted research resulting that Moringa leaves actually contain vitamin A, vitamin C, Vitamin B, calcium, potassium, iron and protein in high amount which is easily consumed and assimilated by human body. In addition, Moringa also known to contain more than 40 anti-oxidant ${ }^{22}$.

\section{Moringa Oleifera Can Increase Breast Milk}

Breastfeeding mothers need nutrition more than during her pregnancy. During breastfeeding, she needs extra energy to heal her health condition after giving birth, daily activities such as forming the breast milk. In the first month after giving birth, ASI production is commonly abundant so that it comes out a lot and sucked by the baby, thus the mothers will become hungry and thirsty faster. In order that the amount of calories is balanced with the needs, then adequate nutrition is also needed because the energy will be reprocessed for forming the breast milk. During breastfeeding, mothers produce about $800-1000 \mathrm{cc}$ of breast milk ${ }^{23}$.

Research on herbs or food which can increase the breast milk production has not been done numerously. Previous research often used animal as the research subject. However, several food and herbs have long been believed to be able to increase the breast milk production. Moringa leaves increases the lactation effect proven by higher increase on mothers' serum prolactin level. Prolactin is the most important hormone in lactation initiation. Galactagogues is a concoction to increase the volume of breast milk and making the milk flow smoothly. Moringa leaves powder is effective galactagogues to increase the volume of breast milk and accelerate it ${ }^{22,24-26}$.

The effect of Moringa oleifera provision on pregnant mothers

Pregnant period is critical phase determining the children's growth and development. Good pregnant outcome is really expected so that it will creates healthy, smart and productive human resource. Research in India proves that mother with malnutrition status causes disruption on fetus growth and cause the mother to give birth to baby with low birth weight ${ }^{25,26}$.

Moringa oleifera has long been used to overcome the malnutrition issue on children, pregnant mothers and breastfeeding mothers. Furthermore, micro nutritional compound in moringa leaves can be used as alternative supplement for pregnant mothers to prevent anaemia and low birth weight. The prevention of anaemia on mothers can decrease the occurrence of complication during the pregnancy and body weight ${ }^{6}$.

\section{The effect of Moringa oleifera provision on} breastfeeding mothers

Breast milk also contains protection compound that can prevent the baby from infectious disease. Providing breast milk also gives extraordinary emotional effect which can affect the inner connection between the mothers and the baby, as well as affect the psychological development of the baby. The provision of exclusive breast milk can optimize the growth of the baby. Factors affecting the provision of breast milk are the mothers who are supported well by the family and lactation education which can increase the mothers' knowledge, attitude and behavior to give exclusive breast milk until 6 months ${ }^{3,26-29}$.

Previous research done by Zakaria in 2016 in Maros District on 70 breastfeeding mothers 6 weeks after giving birth shows that the provision of Moringa leaves extract and powder can increase the breast milk volume, however, the increase on group obtaining the extract was higher that the group obtaining the powder, but it did not affect the breast milk quality (iron, vitamin $\mathrm{C}$ and vitamin $\mathrm{E}$ ) ${ }^{\mathbf{1 5}}$. 


\section{Conclusion}

Moringa oleifera is one of alternative plants believed to have potential to decrease malnutrition, hunger, prevent low birth weight, increase pregnant mothers' $h b$ level, prevent DNA damage due to stress and prevent the occurrence of anaemia on pregnant mothers.

Source of Funding: This study was sponsored by Ministry of research and higher education

Ethical Clearance : Ethical Commission of the Faculty of Public Health of Universitas Hasanuddin Number 1071909130.

\section{Conflict of Interest : None}

\section{References}

1. Sandra fikawati, Ahmad syafiq K karima. Gizi Ibu dan Bayi. Jakarta; 2015.

2. Nur Ulmy Mahmud, Tahir Abdullah, Arsunan, A.A, Burhanuddin Bahar, Veni Hadju, Masyita Muis SS. The determinants of exclusive breastfeeding in 0-6 months infants in Jeneponto Regency. Indian Journal of Public Health Research \& Development. 2019;10(10):1487.

3. Nurmiaty, Arsunan A.A, Saifuddin Sirajuddin MS. The Effect OfEducation Lactation On Breastfeeding Behavior Infant 0-6 Months In Kendari Indonesia. Public Health of Indoenesia. 2016;2(2):19-29.

4. Robert, B. \& G. Clinical Report - Diagnosis and Prevention of Iron Deficiency and Iron-Deficiency Anemia in Infants and Young Children $(0-3$ Years of Age ). American Journal of Public Health. 2018;

5. Ponomban SS, Walalangi R, Harikedua VT. Efektivitas Suplementasi Bubuk Daun Kelor (Moringa oleifera) Terhadap Peningkatan Kadar Hemoglobin Pada Ibu Hamil Yang Menderita Anemia. GIZIDO - Jurnal Ilmiah Gizi. 2013;5(1):36-44.

6. Sreelatha S, Padma PR. Antioxidant activity and total phenolic content of Moringa oleifera leaves in two stages of maturity. Plant Foods for Human Nutrition. 2009;64(4):303-11.

7. Thurber MD, Fahey JW. Adoption of Moringa oleifera to Combat Under-Nutrition Viewed Through the Lens of the "Diffusion of Innovations" Theory. Ecology of Food and Nutrition [Internet]. 2009;48(3):212-25.
Available from: http://www.tandfonline.com/doi/ abs/10.1080/03670240902794598

8. Nur Ulmy Mahmud, Tahir Abdullah, Arsunan A.A., Burhanuddin Bahar VH. Effect of moringa leaves during pregnancy on growth and morbidity in 0-5 months. envermeria clinica. 2020;

9. Masyitha Muis, Veni Hadju, Syamsiar Russeng MFN. International Journal of Current Research and Academic Review. International Journal of Current Research and Academic Review. 2014;4(1):17883.

10. Nurdin MS, Imam A, Thahir A, Hadju V. Supplementations on Pregnant Women and the Potential of Moringa Oleifera Supplement to Prevent Adverse Pregnancy Outcome. International Journal of Science and Healthcare Research. 2018;3(March):71-5.

11. Nadimin. The Influence Provision of Moringa Leaf Exctracy ( Moringa Oliefera ) against the Level of MDA (Malondialdehyde) in Pregnant Women. International Journal of Sciences: Basic and Applied Research (IJSBAR). 2016;27(3):48-56.

12. Iskandar I, Hadju V, As 'ad S, Natsir R. Effect of Moringa Oleifera Leaf Extracts Supplementation in Preventing Maternal Anemia and Low-BirthWeight. International Journal of Scientific and Research Publications [Internet]. 2015;5(1):2250 3153. Available from: www.ijsrp.org

13. Agne-Djigo A, Kwadjode KM, Idohou-Dossou N, Diouf A, Guiro AT, Wade S. Energy intake from human milk covers the requirement of 6-month-old Senegalese exclusively breast-fed infants. British Journal of Nutrition. 2013;110(10):1849-55.

14. Suzana D, Suyatna FD, Andrajati R, Sari SP, Mun A. Effect of Moringa oleifera Leaves Extract Against Hematology and Blood Biochemical Value of Patients with Iron Deficiency Anemia. Journal of Young Pharmacist. 2017;9(1):79-84.

15. Zakaria HV, As S, Bahar B. The Effect of Moringa Leaf Extract in Breastfeeding Mothers against Anemia Status and Breast Milk Iron Content. Internasional Journal of Sciences Basic and Applied Research (IJSBAR. 2015;24(1):321-9.

16. Khuzaimah A, Hadju V, As S, Abdullah N, Bahar B, Riu DS. Effect of Honey and Moringa Oleifera Leaf Extracts Supplementation for Preventing DNA Damage in Passive Smoking Pregnancy. International Journal of Sciences: Basic and 
Applied Research (IJSBAR. 2015;24(1):138-45.

17. Nadimin, Veni Hadju, Suryani As'ad AB. The Extract of Moringa Leaf Has an Equivalent Effect to Iron Folic Acid in Increasing Hemoglobin Levels of Pregnant Women : A randomized Control Study in the Coastal Area of Makassar. International Journal of Sciences: Basic and Applied Research (IJSBAR). 2015;22:287-94.

18. Zakaria, Veni Hadju, Suryani As'ad BB. The Effect of Moringa Leaf Extract in Breastfeeding Mothers against Anemia Status and Breast Milk Iron Content. International Journal of Sciences: Basic and Applied Research (IJSBAR). 2015;24:321-9.

19. Nweze, Nkechinyere Onyekwere and Nwafor F. Phytochemical, Proximate and Mineral Composition of Leaf Extracts of Moringa oleifera Lam. from Nsukka, South-Eastern Nigeria. IOSR Journal of Pharmacy and Biological Sciences [Internet]. 2014;9(1):2319-7676. Available from: www.iosrjournals.org

20. Raguindin PFN, Dans LF, King JF. Moringa oleifera as a galactagogue. Breastfeeding Medicine. 2014;9(6):323-4.

21. Estiyani A, Suwondo A, Rahayu S, Hadisaputro S, Widyawati MN, Susiloretni KA. The Effect of Moringa Oleifera Leaves on Change in Blood Profile in Postpartum Mothers. Belitung Nursing Journal [Internet]. 2017;3(3):191-7.

22. Krusnadi D. Kelor Super Nutrisi. Usat Informasi Dan Pengembangan Tanaman Kelor Indonesia
Lembaga Swadaya Masyarakat - Media Peduli Lingkungan (Lsm-Mepeling). 2015.

23. Paath. Gizi Dalam Kesehatan Reproduksi. Jakarta: ECG; 2005.

24. Titi M K HET and ESW. Effect lactagogue moringa leaves (Moringa oleifera Lam) powder in rats white female wistar. J Basic Appl. 2013;(3):430-4.

25. Fikawati S, Syafiq A. Study on Policy and Implementation of Exclusive and Early Initiation of Breastfeeding in Indonesia. Makara Journal of Health Research. 2011;14(1):17-24.

26. Rantetampang AL., Mallongi A. Risks Assessment Of Cadmium Through Aquatic Biota Consumption From Sentani Lake In Papua, Indonesia. 2013;2(6):2492-501.

27. Mallongi A., Herawaty. Assessment of mercury accumulation in dry deposition, surface soil and rice grain in Luwuk gold mine, Central Sulawesi. Res J Appl Sci. 2015;10(1):22-4.

28. Mallongi, A. P., Parkpian P., Pataranawat SC. Mercury distribution and its potential environmental and health risks in aquatic habitat at artisanal buladu gold mine in Gorontalo Province, Indonesia. Pak J Nutr. 2015;14:1010-25.

29. Mudhaliar RM, Ghouse MSI, Neppali J, Asavadi D, Uppara V, Chinnakotla V. Nutritional Status of Pregnant Women and Newborns in a Secondary Referral Health Care Setting of India. Indian Journal of Pharmacy Practice. 2017;10(1):14-9. 